\title{
A Brief Overview of the Epidemiology of Pheochromocytoma and Paraganglioma in Korea
}

\author{
Yun Mi Choi
}

Department of Internal Medicine, Hallym University Dongtan Sacred Heart Hospital, Hallym University College of Medicine, Hwaseong, Korea

Pheochromocytoma (PCC) and paraganglioma (PGL), jointly referred to as PPGLs, arise from neural crest cells and can develop either in the adrenal medulla or in extra-adrenal paraganglionic tissues [1]. These are rare tumors, with an incidence of 2 to 8 per million [2]. They occur in $0.2 \%$ to $0.6 \%$ of patients with hypertension and are generally thought to account for up to $5 \%$ of adrenal incidentalomas $[3,4]$. Although the prevalence of PPGLs might vary across populations, nationwide epidemiological data on PPGLs are lacking in most countries.

In Korea, epidemiological research on PPGLs has been scarce. A single-center study in 2013 reported the prevalence of PCC among adrenal incidentalomas to be 7.2\% [5]. However, no nationwide report has investigated the epidemiology of PPGLs in Korea. In 2018, the Korean Endocrine Society released the Korean Endocrine Rare Disease Fact Sheet 2018 [6]. As an extension of this fact sheet, in this issue of Endocrinology and Metabolism, Kim et al. [7] investigated the incidence, prevalence, complications, metastasis, and mortality of PPGLs based on data from the National Health Insurance Service between 2003 and 2014. The operational definition of PPGLs was subjects with International Classification of Diseases, 10th Revision (ICD-10) diagnostic codes for adrenal tumors or PGL, and the definition was limited to those who underwent biochemical tests and surgery. Additionally, subjects with diagnostic codes for aldosteronism, Cushing syndrome, and adrenal cortical carcinoma were excluded.

Received: 18 February 2020, Accepted: 24 February 2020

Corresponding author: Yun Mi Choi

Department of Internal Medicine, Hallym University Dongtan Sacred Heart Hospital, Hallym University College of Medicine, 7 Keunjaebong-gil, Hwaseong 18450 , Korea

Tel: +82-31-8086-3655, Fax: +82-31-8086-2499, E-mail:ymchoi@hallym.or.kr
In total, 1,048 subjects were included. The overall prevalence of PPGLs was 2.13 per 100,000 persons. The overall age-standardized incidence rate was 0.18 per 100,000 person-years. Malignant PPGLs accounted for $17.7 \%$ of cases. This was the first nationwide population-based epidemiological study of PPGLs to be conducted in Asia. Previously, Beard et al. [8] reported its incidence to be 0.8 per 100,000 person-years. Another analysis of national cancer registry data from Sweden reported its incidence to be 0.21 per 100,000 person-years [9]. Recently, a Dutch group reported the incidence of PCC and PGL to be 0.46 and 0.11 per 100,000 person-years, respectively, in 2011 to 2015 [10]. That study involved an analysis of the Dutch pathology registry. Compared to the findings of previous studies, the incidence rate in Korea seems to be similar or slightly lower.

Two previous single-center studies have investigated the rate of metastasis and the prognosis of PPGLs in Korea, and found that 29 of $223(13.0 \%)$ and 33 of $299(11.0 \%)$ of cases were metastatic, respectively $[11,12]$. In comparison to those two previous studies, this study reported a slightly higher rate of malignancy, which might have resulted from the operational definition, as cases were not confirmed by pathologic results.

Kim et al. [7] also evaluated the prognosis of PPGLs. The 5-year survival rates for non-metastatic and metastatic PPGLs at diagnosis were $97 \%$ and $84 \%$, respectively. Catecholamine excess, local growth, and metastatic disease all contributed to increased morbidity and mortality in patients with PPGL. How-

\footnotetext{
Copyright $\odot 2020$ Korean Endocrine Society

This is an Open Access article distributed under the terms of the Creative Commons Attribution Non-Commercial License (https://creativecommons.org/ licenses/by-nc/4.0/) which permits unrestricted non-commercial use, distribution, and reproduction in any medium, provided the original work is properly cited.
} 
ever, mortality was found to be caused mainly by metastatic disease [13]. Additionally, in this study, metastatic PPGLs at diagnosis or during the follow-up period were associated with a 2.40-fold higher risk of mortality than non-metastatic PPGLs, adjusted for age, sex, cerebrovascular diseases, cardiovascular disease, diabetes mellitus, and fractures.

In contrast to previously published single-center reports on PPGLs, a rare type of endocrine tumor, it is noteworthy that this study used national data, even though there may have been some inevitable limitations due to the use of a database containing diagnostic codes without pathological confirmation. This study provides an overview of epidemiology of PPGLs in Korea and further encourages other researchers to conduct epidemiological analyses of rare endocrine diseases. Furthermore, this epidemiological study might provide a basis for additional clinical and experimental research on PPGLs.

\section{CONFLICTS OF INTEREST}

No potential conflict of interest relevant to this article was reported.

\section{ORCID}

Yun Mi Choi https://orcid.org/0000-0001-8209-874X

\section{REFERENCES}

1. Burnichon N, Buffet A, Gimenez-Roqueplo AP. Pheochromocytoma and paraganglioma: molecular testing and personalized medicine. Curr Opin Oncol 2016;28:5-10.

2. DeLellis RA, World Health Organization Classification of tumors. Pathology and genetics of tumours of endocrine organs. Lyon: IARC; 2004.

3. Fishbein L. Pheochromocytoma and paraganglioma: genetics, diagnosis, and treatment. Hematol Oncol Clin North Am
2016;30:135-50.

4. Lenders JWM, Eisenhofer G. Update on modern management of pheochromocytoma and paraganglioma. Endocrinol Metab (Seoul) 2017;32:152-61.

5. Kim J, Bae KH, Choi YK, Jeong JY, Park KG, Kim JG, et al. Clinical characteristics for 348 patients with adrenal incidentaloma. Endocrinol Metab (Seoul) 2013;28:20-5.

6. The Korean Endocrine Society. Korean Endocrine rare disease fact sheet 2018 [Internet]. Seoul: The Korean Endocrine Society; 2018 [cited 2020 Feb 24]. Available from: https://www.endocrinology.or.kr/.

7. Kim JH, Moon H, Noh J, Lee J, Kim SG. Epidemiology and prognosis of pheochromocytoma/paraganglioma in Korea: a nationwide study based on the National Health Insurance Service. Endocrinol Metab (Seoul) 2020;35:157-64.

8. Beard CM, Sheps SG, Kurland LT, Carney JA, Lie JT. Occurrence of pheochromocytoma in Rochester, Minnesota, 1950 through 1979. Mayo Clin Proc 1983;58:802-4.

9. Stenstrom G, Svardsudd K. Pheochromocytoma in Sweden 1958-1981. An analysis of the National Cancer Registry Data. Acta Med Scand 1986;220:225-32.

10. Berends AMA, Buitenwerf E, de Krijger RR, Veeger NJGM, van der Horst-Schrivers ANA, Links TP, et al. Incidence of pheochromocytoma and sympathetic paraganglioma in the Netherlands: a nationwide study and systematic review. Eur J Intern Med 2018;51:68-73.

11. Kim KY, Kim JH, Hong AR, Seong MW, Lee KE, Kim SJ, et al. Disentangling of malignancy from benign pheochromocytomas/paragangliomas. PLoS One 2016;11:e0168413.

12. Choi YM, Sung TY, Kim WG, Lee JJ, Ryu JS, Kim TY, et al. Clinical course and prognostic factors in patients with malignant pheochromocytoma and paraganglioma: a single institution experience. J Surg Oncol 2015;112:815-21.

13. Crona J, Taieb D, Pacak K. New perspectives on pheochromocytoma and paraganglioma: toward a molecular classification. Endocr Rev 2017;38:489-515. 